\title{
Research on the Influence of Interest Rate Liberalization on Commercial Banks' Profitability in China
}

\author{
Lina Wang1, Hengyuan Zhao²*, Ruoxi Li ${ }^{1}$ \\ ${ }^{1}$ School of Economics and Management, North China University of Technology, Beijing 100144, China \\ ${ }^{2}$ Post-Doctoral Scientific Research Workstation, China Export \& Credit Insurance Corporation, Beijing 100033, China \\ *Corresponding author: Hengyuan Zhao, zhao_hengyuan@ 126.com
}

\begin{abstract}
In order to explore the influence of interest rate liberalization on profitability, an empirical analysis is carried out with the panel data of commercial banks in China from 2009 to 2019. Then, the heterogeneity of the impact is studied among different banks. The results show that, first, interest rate liberalization and commercial banks' profitability have an inverted U-shaped relationship, whereby interest rate liberalization would increase the profitability of banks in the early stage but would reduce the profitability after reaching a peak inflection point at the later stage. Secondly, the impact varies among different banks, being more significant in urban commercial banks and large state-owned banks.
\end{abstract}

Keywords: Interest rate liberalization; Profitability; Commercial banks

Publication date: October 2021; Online publication: October 29, 2021

\section{Introduction}

Stable profitability is not only the aim of commercial banks, but also an important factor which refers to the stability of the country's entire financial system. The reform of interest rate liberalization has been accelerating in China since 1993 and has become an important measure to promote the economic development in the country. Interest rate liberalization can impose an impact on banks' profitability by changing its liabilities, asset management, and financialization. Therefore, an empirical analysis is carried out using the panel data of commercial banks in China from 2009 to 2019, through which the key role of interest rate liberalization in China can be recognized in order to look for effective ways to improve the profitability of commercial banks and the stabilization of China's financial system.

\section{Theoretical analysis and econometric model}

Interest rate liberalization has lasted for decades in China. There are many relevant studies at home and abroad. McKinnon and Edward Shaw ${ }^{[1,2]}$ initially put forward the theory of financial repression and financial deepening, which is the foundation theory of liberalization. They advocated that the key to financial repression and financial deepening is the deregulation of real interest rate. Interest rate liberalization imposes a significant impact on the profitability of commercial banks ${ }^{[3]}$, credit risk ${ }^{[4]}$, industry market concentration ${ }^{[5]}$, etc.

Researchers have not reached a consensus about how interest rate liberalization influences banks' profitability. There are even some contradictory views, where interest rate liberalization can lead to expansion or narrowing of profitability. Some others believe that the impact is U-shaped or inverted Ushaped ${ }^{[6,7,8,9,10]}$. 
Given the contradiction, a further step is required. Although many scholars have used various methods, they have not reached a consensus or conclusion yet. New economic factors need to be added for further comprehensive analysis. It is also necessary to identify whether the impact is different among banks with different characteristics.

According to the research purpose, the econometric model is set as follows:

$$
\mathrm{PRO}_{\mathrm{it}}=\mathrm{C}+\sigma \mathrm{IRL}+\sum_{\mathrm{m}=1}^{7} \alpha_{\mathrm{m}} \mathrm{X}_{\mathrm{lit}}^{\mathrm{m}}+\sum_{\mathrm{n}=1}^{3} \beta_{\mathrm{n}} \mathrm{X}_{2 \mathrm{it}}^{\mathrm{n}}+\gamma_{\mathrm{i}}+\mu_{\mathrm{t}}+\varepsilon_{\mathrm{it}}
$$

Among them, the dependent variable, $\mathrm{PRO}_{i t}$, is the profitability of bank $\mathrm{i}$ in year $\mathrm{t}$. IRL is the core independent variable, indicating the level of interest rate liberalization.

This study uses the weighted average of the real interest rate, interest rate determination method, and interest rate floating range to measure interest rate liberalization (IRL) ${ }^{[11,12]}$. The value range is $[0,3]$.

$\mathrm{X}_{1}$ and $\mathrm{X}_{2}$ are control variables, representing micro control variables and macro control variables. The micro control variables include asset size, loan, risk aversion, credit risks, operating risk, liquidity risk, and banking structure. Macro control variables include market competition, economic growth rate, and monetary policy. $\gamma_{\mathrm{i}}$ and $\mu_{\mathrm{t}}$ denote individual fixed effect and period fixed effect, respectively; $\varepsilon_{\mathrm{it}}$ is the error term. The focus is mainly on the value of $\sigma$.

Figure 1 shows the trend of interest rate liberalization measured by subtracting the inflation rate from the nominal interest rate from 2009 to 2019. This study divides the level of interest rate liberalization into four levels: complete suppression, partial suppression, partial liberalization, and complete liberalization, equaling $1,2,3$, and 4 , respectively.

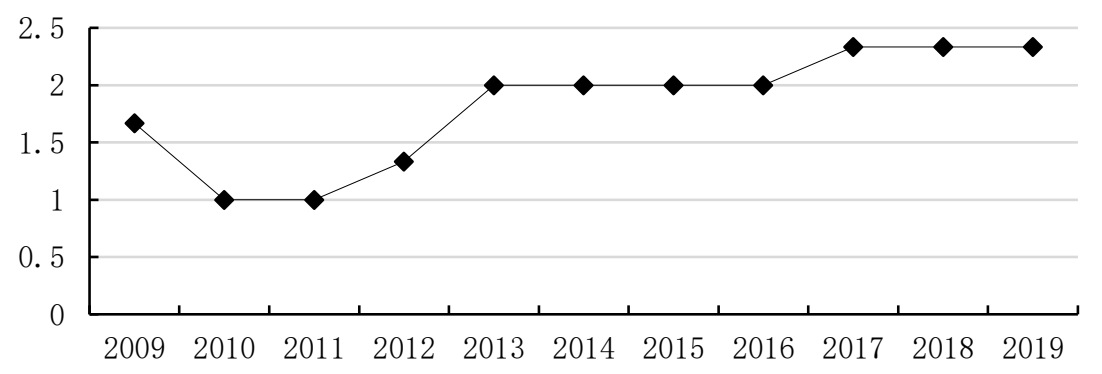

Figure 1. Interest rate liberalization

\section{Empirical results}

\subsection{Variable description}

The data were obtained from Wind Information, BankScope database, and the annual reports of banks. Table 1 presents the descriptive statistics of the variables. The average PRO is $2.48 \%$, with the maximum and minimum of $5.905 \%$ and $0.185 \%$, respectively, indicating that there is a big difference among commercial banks. The maximum value of interest rate liberalization (IRL) is 2.333 and the minimum value is 1, indicating that China's interest rate liberalization has made great progress over the past 10 years. Risk aversion (RA), credit risk (CR), and liquidity risk (LR) are quite different among the banks. The economic growth rate, LGDP, shows that the economic growth rate has slowed down in China. In addition, the monetary policy (M2) has changed significantly. 
Table 1. Summary statistics

\begin{tabular}{ccccc}
\hline Variable & Mean & Standard deviation & Minimum & Maximum \\
\hline NIM & 2.480 & 0.839 & 0.185 & 5.905 \\
IRL & 1.989 & 0.383 & 1.000 & 2.333 \\
LNTA & 18.060 & 1.639 & 15.340 & 22.180 \\
LNLO & 17.270 & 1.678 & 14.580 & 21.600 \\
RA & 0.069 & 0.013 & 0.034 & 0.122 \\
CR & 0.014 & 0.009 & 0.0003 & 0.133 \\
RISK & 4.616 & 1.417 & 0.727 & 9.751 \\
LR & 0.214 & 0.105 & 0.033 & 0.651 \\
BC & 1.689 & 0.423 & 0.941 & 4.680 \\
MC 4 & 0.416 & 0.055 & 0.359 & 0.531 \\
LGDP & 0.045 & 0.026 & -0.029 & 0.101 \\
M2 & 14.130 & 0.286 & 13.320 & 14.500 \\
\hline
\end{tabular}

\subsection{Baseline results}

Table 2 shows the regression results. The columns that are labelled as (1), (2), and (3) shows the results with no control variable, micro control variables, as well as both micro and macro control variables, respectively. The coefficient of interest rate liberalization is significantly positive, while the square term of interest rate liberalization is significantly negative. This indicates that the relationship between interest rate liberalization and banks' profitability is an inverted U-shaped. With the deepening of interest rate liberalization, the profitability of banks increases significantly. However, when it reaches a certain level, the influence changes and shows a significant negative impact on the profitability of banks.

Table 2. Regression results of benchmark model

\begin{tabular}{cccc}
\hline Variable & $\mathbf{( 1 )}$ & $\mathbf{( 2 )}$ & $\mathbf{( 3 )}$ \\
\hline IRL & $0.043^{* * *}$ & $0.056^{* * *}$ & $0.036^{* * *}$ \\
& $(7.74)$ & $(7.19)$ & $(3.95)$ \\
IRL ${ }^{2}$ & $-0.015^{* * *}$ & $-0.017 * * *$ & $-0.010^{* * *}$ \\
& $(-9.19)$ & $(-7.61)$ & $(-3.63)$ \\
LNTA & & $-0.016^{* * *}$ & -0.003 \\
& & $(-5.33)$ & $(-1.22)$ \\
LNLO & $0.011^{* * *}$ & $0.011^{* * *}$ \\
& & $(5.15)$ & $(4.24)$ \\
RA & & $0.180^{* * *}$ & $0.235^{* * *}$ \\
& & $(4.14)$ & $(5.83)$ \\
CR & -0.062 & 0.011 \\
& & $(-1.08)$ & $(0.25)$ \\
RISK & 0.002 & 0.000 \\
& & $(1.39)$ & $(0.03)$ \\
LR & & $0.019 * * *$ & 0.007 \\
& & $(3.61)$ & $(1.48)$ \\
\hline
\end{tabular}

(Continued on the next page) 


\begin{tabular}{cccc}
\hline Variable & $(1)$ & $(2)$ & $(3)$ \\
\hline $\mathrm{BC}$ & & 0.000 & $0.000^{* *}$ \\
& & $(0.50)$ & $(2.09)$ \\
$\mathrm{MC}_{4}$ & & & -0.014 \\
& & & $(-0.93)$ \\
$\mathrm{LGDP}$ & & & $-0.000^{* *}$ \\
& & & $(-2.00)$ \\
$\mathrm{M} 2$ & & & 0.046 \\
& & & $(1.58)$ \\
Constant & 0.000 & 0.055 & $-0.151^{* * *}$ \\
& $(0.07)$ & $(1.41)$ & $(-3.21)$ \\
Observations & 629 & 582 & 582 \\
$\mathrm{R}^{2}$ & 0.328 & 0.541 & 0.650 \\
Individual effect & YES & YES & YES \\
Annual effect & YES & YES & YES \\
\hline
\end{tabular}

Note: $* * *$ denotes $\mathrm{p}<0.001, * *$ denotes $\mathrm{p}<0.01, *$ denotes $\mathrm{p}<0.05$.

Among the micro control variables, loan (LNLO), risk aversion (RA), and banking structure (BC) have significant effects on the profitability. The coefficients of credit risks (CR) and liquidity risk (LR) are not significant. Among the macro control variables, the coefficients of economic growth rate (LGDP) and market competition $\left(\mathrm{MC}_{4}\right)$ are insignificant. The variable coefficient of monetary policy (M2) is much smaller, showing that the change of annual money supply has minimal negative impact on the profitability of commercial banks.

\subsection{Heterogeneity analysis}

According to the characteristics of different banks, this study divides the samples into four categories: large state-owned banks, joint-stock banks, urban commercial banks, and rural commercial banks. Table 3 shows the regression results. The effect is much larger in rural commercial banks and large state-owned banks, while the effect is smaller in joint-stock banks and urban commercial banks. Joint-stock banks are superior in their capital power and operating capabilities in addition to having a variety of business types. Most urban commercial banks and rural commercial banks are small- or medium-sized. They have weak bargaining power and a relatively low operation level.

\subsection{Robustness}

In this section, the robustness of the results is determined. "Interest income-interest expense/profit-seeking assets" is used to represent the banks' profitability, and the empirical results are consistent with the conclusion.

\section{Conclusion}

The study analyzed the relationship between interest rate liberalization and the profitability of banks. The results showed as follows: (1) interest rate liberalization imposed an inverted U-shaped impact on profitability; (2) the impact is more significant in urban commercial banks and large state-owned banks. 
Table 3. Heterogeneity analysis

\begin{tabular}{ccccc}
\hline Variable & Rural commercial banks & City commercial banks & Joint-stock banks & Large state-owned banks \\
\hline IRL & $0.044^{*}$ & $0.037^{* * *}$ & $0.039^{* * *}$ & $0.040^{* * *}$ \\
& $(1.88)$ & $(2.82)$ & $(3.85)$ & $(5.33)$ \\
IRL $^{2}$ & $-0.014^{*}$ & $-0.011^{* *}$ & $-0.013^{* * *}$ & $-0.013^{* *}$ \\
& $(-1.99)$ & $(-2.58)$ & $(-4.39)$ & $(-4.30)$ \\
Controls & YES & YES & YES & YES \\
Constant & -0.084 & $-0.217^{* * *}$ & $-0.111^{* *}$ & 0.137 \\
& $(-0.43)$ & $(-3.58)$ & $(-2.37)$ & $(0.70)$ \\
Observations & 75 & 382 & 86 & 39 \\
$\mathrm{R}^{2}$ & 0.776 & 0.680 & 0.767 & 0.969 \\
Individual effect & YES & YES & YES & YES \\
LGDP & 0.045 & 0.026 & -0.029 & 0.101 \\
Annual effect & YES & YES & YES & YES \\
\hline
\end{tabular}

\section{Funding}

The study was supported by The Research Start-up Funds of North China University of Technology (Project Number: 110051360002).

\section{Disclosure statement}

The authors declare that there is no conflict of interest.

\section{Author contributions}

Lina Wang contributed to the conception of the study and the revision of the manuscript. Hengyuan Zhao performed the data analyses and wrote the manuscript. Ruoxi Li contributed to data curation.

\section{References}

[1] McKinnon RI, 1973, Money and Capital in Economic Development, The Brookings Institution, Washington, D.C.

[2] Shaw E, 1973, Financial Deepening in Economic Development, Oxford University Press, New York.

[3] Xu B, Zheng C, 2018, Analysis of the Influential Factors on the Profitability of Chinese Commercial Banks under the Background of Interest rate liberalization: Based on the Empirical Research of 16 Listed Commercial Banks. Nanjing Journal of Social Sciences, (03): 31-37.

[4] Chen L, 2020, An Empirical Study on the Impact of Interest rate liberalization on the Credit Risk of Joint-Stock Banks-Based on Panel Data of Six Joint-Stock Banks. China Journal of Commerce, (04): 70-72.

[5] Zhang N, 2018, Research on Interest Rate Risk Management of Commercial Banks under the Background of Interest Rate Liberalization. University of International Business and Economics.

[6] Ba S, Hua Z, Zhu Y, 2012, International Comparison of Interest Rate Liberalization: Path, Performance and Market Structure. Journal of Central China Normal University (Humanities and Social Sciences), 51(05): 33-46. 
[7] Cheng G, 2016, Research on the Influence of Individual Factors of Commercial Banks on Net Interest Margin under the Marketization of Interest Rate. Market Modernization, (11): 114-116.

[8] Huang X, Li X, Zeng M, 2016, The Impact of Interest Rate Liberalization on the Profits of Commercial Banks-Based on the Analysis of ICBC. Accounting Learning, (10): 231-233.

[9] Peng J, Wang S, Guan T, 2016, Does Interest Rate Liberalization Narrow Interest Margins of Commercial Bank? Empirical Evidence Based on Chinese Banking Industry. Journal of Financial Research, (07): 48-63.

[10] Xiao X, Wu Y, 2011, The Impact of America's Market-based Interest Rate Reform on the Banking Sector. Studies of International Finance, (01): 69-75.

[11] Shen C, Zhao S, Li Y, 2020, Interest Rate Liberalization, Non-interest Income and Net Interest Margin of Banks - The Different Influence Paths of Classified Non-interest Income. Statistical Research, 37(05): 68-81.

[12] Tao X, Chen M, 2013, Measure and Reform Implications of China's Interest Rate Liberalization. Journal of Zhongnan University of Economics and Law, (03): 74-79, 160.

[13] Zhang X, Liang Q, 2010, On the Performance of China's Interest Rates Liberalization. The Journal of Quantitative \& Technical Economics, 27(06): 35-46.

[14] Zhao S, Chen Q, 2019, Interest Rate Liberalization and the Transmission of Monetary Policy through Bank Lending Channel. Modern Economic Science, 41(04): 109-117. 